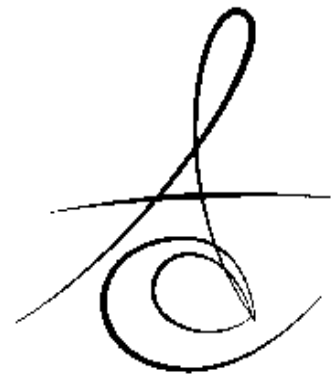

Makale Kodu/Article code: 1812

Makale Gönderilme tarihi: 01.08 .2014

Kabul Tarihi: 30.10.2014

\section{RESTORATİF DİŞ HEKİMLİĞİNDE NANOTEKNOLOJİ}

\section{NANOTECHNOLOGY IN RESTORATIVE DENTISTRY}

\author{
Dt. Fjolla KOSHí \\ Dr. Faruk ER*
}

\section{ÖZET}

Gün geçtikçe gelişen teknoloji, doğada meydana gelen olayların moleküler düzeyde incelenmesi için bilim dünyasına olanaklar sunmaktadır. Yirmi birinci yüzyıla girilmesiyle birlikte stratejik önemi bir o kadar daha artmış olan nanoteknoloji; materyallerin atomik veya moleküler düzeyde manipüle edilmesiyle mikroskopik aletler üretme sanatıdır. Nanoölçek düzeyde müdahaleyi mümkün kılan bu teknoloji; sağlıkta araştırma, koruma ve iyileştirme alanlarında insanlığın yeni bir atılım yapmasına katkı sunmaktadır.

Bilim ve teknolojideki bu gelişmeler diş hekimliğiyle ilişkili doku mühendisliğinde, implantolojide, protetik diş tedavisinde ve restoratif diş tedavisinde yaygın olarak kullanılmaktadır. Özellikle rezin bazlı kompozit teknolojisi restoratif diş hekimliğinde süren araştırmalar ve uygulanacak tedavilerde çı̆ır açan bir gelişme olmuştur. Nanoteknoloji alanındaki gelişmeler sürdükçe restoratif diş hekimliği alanında da yeni ufuklar açılmaya devam edecektir.

Anahtar Kelimeler: Nanoteknoloji, nanokompozit, nanodoldurucu

\section{ABSTRACT}

The progression of technology provides opportunity to investigate the natural events in the molecular level. Its strategic value has been increased in the twentyfirst century since it is; "the art of manipulating materials on an atomic or molecular scale especially to build microscopic devices". As an enabling technology; the application of nanotechnology has the potential to contribute research, prevention and healing in health sciences.

Especially these developments in science and technology are widely used in tissue engineering regarding dentistry, implantology, prosthetics and restorative treatment. Resin-based composite technology has been counted as breaking new ground in researches and treatments in restorative dentistry. As long as nanotechnology develops; new expansions will continue in restorative dentistry.

Keywords: Nanotechnology, nanocomposite, nanofiller.

tanımlanmıştır. Nano, Yunancada 'cüce' anlamına gelen sözcükten (nannos) türemiş olup, kelime olarak fiziksel bir büyüklüğün milyarda biri anlamına gelen bir ön ektir. 1 nanometre (nm), metrenin milyarda birine eşittir. ${ }^{3}$

Nanoteknolojinin uygulama alanları çok geniş olmakla beraber malzeme ve imalat, nanoelektronik ve bilgisayar teknolojisi, havacılık ve uzay çalışmaları, çevre ve enerji, biyoteknoloji ve tarım, tıp ve sağlık gibi sahalarda etkisi ve önemi daha fazladır. Özellikle sağlık alanındaki nanoteknolojik gelişmeler, hastalıkların ve travmatik yaralanmaların tanı, tedavi ve
Nanoteknoloji; zamanın başlamasından bu yana varolmasına rağmen, nobel ödüllü fizikçi Richard $P$. Feynman'ın 1959'da Amerikan Fizik Derneği toplantısında yaptığı "Aşağıda Daha Çok Yer Var (There Is Plenty Of Room At The Bottom)" isimli konuşması; bu kavramın ilk defa ortaya atılması bakımından bir milattır. ${ }^{1}$ Nanoteknoloji terimi ilk defa Taniguchi $^{2}$ tarafından "genel olarak malzemelerin atom ya da moleküler düzeyde işlenmesi, ayrılması, birleştirilmesi ve bozulmasıdır" şeklinde somut olarak
*Yakın Doğu Üniversitesi Diş Hekimliği Fakültesi, Restoratif Diş Tedavisi Anabilim Dalı 
önlenmesini amaçlayan yeni bir bilim dalı olarak nanotıbbı gündeme getirmiştir.

\section{Nanotip}

Nanotıbbın ilk tanımı; nanoyapılar ve nanocihazlar yardımıyla insan vücudundaki biyolojik sistemlerin moleküler düzeyde izlenmesi, kontrol ve tedavi edilmesi şeklinde Freitas ${ }^{3}$ tarafından yapılmıştır. Nanobiyoteknolojinin en popüler dalı nanotıp uygulamalarında sürecin başında önce hedef yaklaşımı belirlenir. Sonrasında belirlenen hedefi bulacak ve onun işlevini kontrol edecek olan nanocihazın üretimine geçilir. ${ }^{4}$ Böylelikle nanotıp sadece mevcut tekniklerde gelişme sunmakla kalmaz, aynı zamanda tamamen yeni cihazların üretilmesini de sağlamaktadır. ${ }^{5}$ Nanotıbbın uygulama alanlarına bakıldığında nanokürelerle ilaç salınımı, doku yapılanmasını gerçekleştirecek nanoteknolojik tasarıma dayalı doku iskeleleri, teşhis ve tedavi amaçlı nanorobotlara rastlamak mümkündür. ${ }^{5,6}$ Nanotıp ile yaşam kalitesini arttırmak için daha kusursuz, daha iyi kontrol edilebilen, daha güvenilir, daha hızlı, daha ekonomik ve çok yönlü uygulamalar gerçekleştirilebilir. ${ }^{5,6}$

\section{Nanodişhekimliği}

Yıllar boyunca, diş hekimliğindeki gelişmeler, güvenilir ve az ağrılı dental uygulamalara olanak sağlamıştır. Günümüzde nanomateryaller, nanorobotlar ve doku mühendisliğini de kapsayan biyoteknolojilerin hep birlikte kullanımıyla nanodişhekimliğinin gelişmesi yönündeki çalışmalar yoğun bir şekilde devam etmektedir. Bu çalışmaların amacı mükemmel ağız sağlığı sağlayabilmektir. Bu amaç doğrultusunda nanoteknoloji; diş hekimliğinde doku mühendisliğinde, implantolojide, protetik diş tedavisinde ve restoratif diş tedavisinde kullanılmaktadır. ${ }^{3,7}$

Restoratif diş tedavisinde çığır açan gelişmelerden biri rezin bazlı kompozit teknolojisidir. Kompozit rezinlerde nanoteknolojinin kullanılmasıyla; parlatılabilme özelliği (mikrofillerin tipik özelliği) yüksek, aşırı stres yüklemelerine karşı iyi mekanik özellik gösteren (hibrit kompozitlerin tipik özelliği), tüm dişlerde kullanılabilen nanodoldurucular içeren nanokompozitler piyasaya sürülmüştür. ${ }^{8}$

\section{Nanokompozitler}

İçerdikleri inorganik doldurucu büyüklüğüne göre kompozit rezinler; megafil, makrofil, midifil, minifil ve mikrofil kompozitler şeklinde sınıflandırılmıştır. Daha sonraki yıllarda ise kompozit rezinin yapısına değişik büyüklükte doldurucuların eklenmesiyle hibrit kompozit rezinler üretilmiş ve ardından diş hekimliğinde nanoteknolojinin kullanılmasıyla nanopartikül içeren nanodoldurucular yapıya katılmış ve partikül büyüklüğü 5-100 nm'ye kadar küçültülmüş nanokompozitler piyasaya sürülmüştür. ${ }^{9-12}$

Nanodişhekimliğinde malzemelerin üretilebilmesi için yukarıdan aşağı "Top Down" ve aşağıdan yukarı "Bottom Up" olmak üzere 2 yöntem kullanılmaktadır. Yukarıdan aşağıya yaklaşım kapsamındaki yöntemlerde söz konusu malzemeye mekanik ve kimyasal müdahalelerle dışarıdan enerji verilir. Bu işlem sonucunda malzemenin nanoölçeğe kadar küçültülmesi hedeflenir. Yukarıdan aşağıya yaklaşımlara sayılabilecek örnekler arasında mekanik öğütme ve aşındırma bulunmaktadır. Bu tekniklerde geleneksel öğütme işlemlerinden çok daha fazla enerji tüketimi gerçekleşmektedir. Dolayısıyla bu işlemler yüksek enerjili öğütme veya yüksek hız değirmenleri olarak bilinmektedir. ${ }^{13}$ Aşağıdan yukarıya yaklaşımlara ait yöntemler olarak; atomik veya moleküler boyuttaki yapıların kimyasal reaksiyonlarla büyütülmeleri ve sonuç olarak partiküllerin elde edilmesi işlemleri sayılabilir. ${ }^{14}$

Nanopartiküller kompozit rezinlere tek başına veya nanoöbekler (nanocluster) halinde ilave edilmektedir. Geleneksel kompozitler için doldurucu üretilirken büyük partiküller millenerek boyutları küçültülür. Ancak bu yöntemler doldurucu büyüklüğünü 100 nm'nin altına indiremez. ${ }^{15,16}$ Nanoteknoloji ile dental kompozitler için uygun, nanoboyutlu doldurucu partiküller üretmek mümkün olmuştur. Nanodoldurucuların üretiminde, geleneksel dolduruculardan farklı olarak yukarıdan aşağı "Top Down" yöntemi kullanımaktadır. Bu sayede kompozit rezin matriksine daha fazla miktarda doldurucu eklenebilmiştir. ${ }^{15}$

$\mathrm{Bu}$ yöntemle 4 çeşit nanopartikül elde edilmiştir.

\section{1-Oksid Nanopartiküller}

Nanopartiküllerin yüzeylerini işlevsel hale getirmek için 2 strateji bulunmaktadır. Birincisine göre; organik grup, nanopartikül veya nanoöbeğin izolasyonu sonrasında eklenirken diğer bir yöntemde ise, nanopartiküllerin sentezi sırasında organik grubun eklenmesi söz konusudur. İkinci yöntemle elde edilen oksid nanopartiküllerin yüzeyindeki terminal O- 
veya $\mathrm{OH}$ grupları silikon halindedir (halojen oksid tuz) bazen de alkoksidlerle organik fonksiyonellik içerisinde reaksiyona girmektedir. ${ }^{17}$ Oksit nanopartiküller nanokompozitlerin üretiminde kullanılmaktadır. $\mathrm{Bu}$ yöntemle elde edilen nanokompozitler 2 tiptir:

\section{a)Nanofil Kompozitler}

Nanofil kompozitlerde inorganik doldurucu partiküllerin büyüklüğü 0.005-0.01 $\mu \mathrm{m}$ (5-100 nm) olup, görünür ışı̆̆ın dalga boyundan daha küçük oldukları için yüksek translusensi göstermektedirler. Görünür ışık ile abzorbsiyon veya saçıım gibi etkileşimlere girmediklerinden dolayı üstün optik özellik sergilemektedirler. Daha geniş bir renk seçeneğiyle daha estetik restorasyonlar yapılmasına olanak sağlamaktadırlar. ${ }^{16,18,19}$

Silika partiküller, en yaygın kullanılan nanometrik partiküllerdir. Silika nanopartiküllerin yüzeyi silan (MTPS- 3-metakriloksipropiltrimetoksi silan) ile kaplıdır. MTPS coupling ajanı ara faz olarak da bilinir ve organik polimer ile inorganik faz arasında sıkı bir bağlanma sağlar. Nanokompozitlerde silika partiküllerin yüzeyi silan bağlanma ajanıyla önceden kaplanmış ve silika partikülleri yüzeyinde tek moleküllü ve çift fonksiyonlu çok ince bir katman oluşturmuştur. Bu katmandaki moleküllerin bir ucu silika partikülerinin yüzeyinde var olan hidroksil gruplarıyla, diğer ucu organik matriksteki polimer ile bağlanmıştır. Silan bağlanma ajanı rezinin fiziksel ve mekaniksel özelliklerinde önemli rol oynamaktadır. ${ }^{20}$ Nano boyutlu silika ve zirkonyum kökenli inorganik doldurucu partiküllerin polimer matriks içinde bir araya toplanması, büyüklüğü 20-75 nm boyutunda olan nanoöbekleri oluşturur. Nanoöbekler arasındaki boşlukların nanometrik partiküllerle doldurulması, partikül yüzdesini arttırarak kompozitin aşınmaya karşı direncinin artmasına ve polimerizasyon sonucu oluşan büzülmenin bir miktar azalmasına neden olur. ${ }^{20}$

\section{b)Nanohibrit Kompozitler}

Farklı büyüklükte doldurucu partiküller içeren 2 farklı kompozit rezin karışımına hibrit kompozit denir. Her 2 kompozit rezinin özelliklerini taşımalarına karşın hibrit türünün belirlenmesinde yüzdesi en fazla olan partiküllerin adı kullanılır, yani nanopartiküllerin yüzdesinin fazla olduğu kompozit rezin karışımlarına nanohibrit kompozit denmektedir. ${ }^{13}$
Hibrit kompozitlerde kolloidal silika ve ağır metaller içeren cam partikülleri harmanlanmış, inorganik doldurucu olarak organik matrikse katılmıştır. Buna bağlı olarak doldurucu partikül yüzdesi ağırlık bakımından \%10-20'si kolloidal silika olmak üzere \%75-80'e ulaşmıştır. Submikron büyüklüğündeki inorganik doldurucu partiküller $(1-3 \mu \mathrm{m})$ büyük partiküller arasına gelişi güzel serpiştirildiği için yüzey düzgündür. Bu nedenle, estetiğin ön planda olduğu anterior restorasyonlarda, labial veneerlerde ve stres altında bulunan bölgelerde yaygın olarak kullanımı önerilmektedir. ${ }^{20}$

\section{Silseskioksan Nanopartiküller}

Silseskioksan terimi; $\mathrm{RSiO}_{1.5}$ deney formülündeki tüm yapılar için kullanılmaktadır. Buradaki R; hidrojen veya herhangi alkil, alkilen, aril ve arilen grup veya söz konusu grupların organofonksiyonel türevlerine karşılık gelmektedir. Silseskioksan; rastgele şekillenmiş yapılar, merdiven şeklinde yapılar, kısmi veya tam kafes yapılar içermektedir. Bu materyallerin içeriğinde oksijenin silikona oranı 1.5 'tir. $\mathrm{Bu}$ oran sayesinde silika $\left(\mathrm{RSiO}_{2}\right)$ ile silikonun ( $\mathrm{RSiO}$ ) arasında özgün fiziksel özelliklere sahip bir hibrit kompozit elde edilmektedir. Bunlar polisilik oligomerler ve polimerlerin yapısında bulunmaktadırlar. Polihedral oligomerik silseskioksan yapılar, POSS materyaller olarak da bilinmektedirler. POSS bileşiklerin çoğu; oldukça simetrik, tam kondense silikon-oksijen iskelet yapılara sahiptirler. Bu bileşikler fiziksel olarak geniş, polimer ölçülerine benzer ve nanoölçektedirler. POSS molekülü, "kovalent bağlı reaktif fonksiyonel" bir yapıdadır. ${ }^{16}$

Non-reaktif gruplar POSS'un çeşitli polimerik segmentlerle olan çözünürlük ve uyumluluğunu arttırmak için tercih edilmiştir. Ayrıca POSS'un polimer matriksle kullanımı; moleküler düzeyde destek sağlaması ve inorganik iskelette seramiksi özellik göstermesi gibi fiziksel ve mekanik avantajlar sunmaktadır.

POSS, kompozitlerin optik özelliklerini arttırmak ve polimerizasyon büzülmesi gibi çeşitli dezavantajlarını azaltmak üzere üretilmiştir. ${ }^{21}$ Yapılan bir çalışmada $^{21}$ monometakril fonksiyonlu POSS, diğer metakril monomerlerle kopolimerize edilmiş ve çalışmanın sonucunda ağırık bakımından sadece $\% 5$ fonksiyonelize POSS monomer içeren kompozit rezinde belirgin biçimde polimerizasyon büzülmesinin azaldığı ve mekanik özelliklerinin geliştiği bildirilmiştir. 


\section{Polimer Şablonlu Nanopartiküller}

Polimerlerin supramoleküler demetleri kendilerine özgü bir şekilde sıralanır ve yapılanırlar. Bu sayede nanoölçekli bir düzende materyallerin sentezi sağlanmış olur. Doğal ve sentetik polipeptidler, lipidler, sentetik fonksiyonel polimerler ve sürfaktanlar bu materyallere örnektir. Yüksek moleküler ağırlıktaki poliakrilik asit; çapları 100 nm'den küçük iğne şeklindeki nanoapatit kristallerin sentezinde kullanılır. ${ }^{22}$ Kitozan ve kollajen gibi doğal polimerlerden "poröz iskele" olarak yararlanılır. ${ }^{23}$ Sürfaktan molekülleri nanopartiküllerin sentezinde şablon olarak fonksiyon görebilirler. $\mathrm{Bu}$ nanopartiküller, dental adezivleri desteklemek amaçlı kullanılabilir. ${ }^{24}$

\section{Kalsiyum Fosfat ve Kalsiyum Florid Nanopartiküller}

Kalsiyum, flor, fosfat gibi iyon salan materyaller diş yapısındaki remineralizasyonu sağlamaktadırlar. Bu yüzden bu iyonları içeren nanopartiküllerin nanokompozitlerde kullanılması gündeme gelmiştir.

$\mathrm{Xu}$ ve ark. $^{25}$ nanokompozitlerde dikalsiyum fosfat nanopartikül sentezini inceledikleri çalışmalarında; uygun fiziksel dayanıklılı̆ı sağlamak için kompozit rezinin içine nanosilika kristaller yerleştirilmesi gerektiğini bildirmişlerdir. Li ve ark. ${ }^{26}$ kompozit rezinlere mine rengini sağlamak için nanohidroksiapatit (HAP) eklemişler ve bu nanomolekülün çürük önleyici etkisinin bulunduğunu ancak konvansiyonel hidroksiapatitte aynı etkiye rastlanmadığını belirtmişlerdir.

\section{Dental Adezivlerde Nanoteknoloji}

Dental adezivlerin koheziv dayanıklılığını arttırmak için günümüzde polimerize silanla işlem görmüş doldurucu partiküller kullanılmaktadır. Adezivler yeterince visköz olmadığından doldurucu partiküller depolanma süresince çökmeye yatkındırlar ve bu da verimliliklerini etkilemektedir. Bu dezavantajlarını en aza indirmek için, farklı silanla işlem görmüş 5-7 nm boyutunda silika veya zirkon nanopartiküller dental adezivlere eklenmiştir. Singlebond Plus (3M ESPE, St.Paul, ABD) ve Scotchbond SE (3M ESPE, St. Paul, $A B D$ ) adezivler nanopartikül içeren adeziv sistemlere örnektir. Son zamanlarda geliştirilen adeziv sistemlerde radyoopasiteyi sağlamak için yapıya zirkon nanopartiküller eklenmiştir. ${ }^{27}$

Nagano ve ark. ${ }^{28}$ dental adezivlerin dayanıklılığını uzatmak için 4-META/MMA-TBB rezin sement uygulamasından önce yapıya kolloidal platinyum nanopartiküller (CPN) eklemişler ve bunun sonucunda ara yüzde konversiyon sonuçlarının konservatif prosedürlere göre daha başarılı olduğunu rapor etmişlerdir.

Cam İyonomer Sistemlerde Nanoteknoloji Konvansiyonel ve rezin modifiye cam iyonomerler; ağız ortamında flor salınımına ve dişlerin remineralizasyonuna katkıda bulunan dental materyallerdir. Bu materyaller, nemli ortama çok iyi uyum göstermekte ve postoperatif hassasiyetin kontrolünü sağlamaktadır ancak, optik özellikleri estetik restorasyon gerektiren durumlarda yeterli görülmemektedir. ${ }^{29}$ $\mathrm{Bu}$ yararlı özelliklerinden faydalanmak ve estetik özelliklerini geliştirmek için rezin modifiye cam iyonomer (RMCİ) siman geliştirilmiştir. ${ }^{30,31} \mathrm{Bu}$ materyallerde silika öbekleri ve zirkonya ile birlikte aglomerize olmayan zirkoniyum nanomerler iki pat halinde RMCI'ye eklenmiştir (Ketac ${ }^{\mathrm{TM} N a n o, ~ 3 M ~ E S P E, ~ S t . ~ P a u l, ~}$ ABD). Nanoiyonomerlerin görsel opasitesi konvansiyonel cam iyonomerlere göre oldukça düşük bulunurken mekanik özellikler, flor salınımı, remineralizasyon özelliği ve adezyon dayanıkılığı açısından kesin bir sonuca varılamamıştır ${ }^{32,33}$.

Geleneksel cam iyonomerlerin tozuna iterbiyum florür ve baryum sülfat nanopatiküllerinin eklenmesinin çalışma süresini ve başlangıç sertleşme süresini kısalttığı, ancak baryum sülfatın daha fazla eklenmesinin sertleşme reaksiyonuna engel olduğu bildirilmiştir. ${ }^{34,35}$

Moshverinia ve ark. $^{36}$ yaptıkları çalışmada nanohidroksiapatit kristaller ve nanofloroapatiti, etanol bazlı sol-jel metodla sentezlemişledir. Mekanik özelliklerini geliştirmek için yapıya floroaluminosilika tozu katılmış ve konvansiyonel cam iyonomer ile birleştirilmiştir. Çalışmanın sonucunda, elde edilen cam iyonomer simanın kompresif dayanıklılık ve çalışma süresi gibi özellikleri yetersiz görülmüş ve nanopartikül kullanımının üstün bir ürün garantisi vermediği, materyallerin dikkatlice dizayn ve optimizasyonunun gerektiği rapor edilmiştir.

\section{Dental Materyallerde Nanopartikül Kullanımının Sağladığı Avantajlar}

Dental materyallerde nanopartiküllerin kullanılmasının öncelikli nedenlerinden biri; mekanik dayanıklııı ve aşınma direncinden ödün vermeden, materyalin optik özelliklerini geliştirmektir. Restoratif maddelerin estetik görünümleri; renk, şeffaflık ve düzgünlük

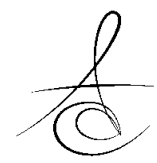


gibi optik özelliklerden etkilenmektedir. Mine ve tüm estetik dolgu maddeleri bir ölçüde şeffaftır. Şeffaflık düzeyi, diş ya da restorasyonun ışı̆̆ı dışarı yansıtma öncesindeki ışık penetrasyonu derinliğine bağlıdır. ${ }^{20}$

Nanokompozit doldurucularının boyutu, görünür ışığın dalga boyundan çok daha küçük olduğundan bu partiküllerden oluşan nanokompozitler yüksek translusensi gösterirler, bu da geniş bir renk seçeneğinin olmasını sağlamaktadır. Tüm bu parametreler restorasyonun estetik olması açısından son derece önemlidir. ${ }^{16}$

Kompozitlerdeki geniş renk ve opasite seçenekleri klinisyenlerin doğal diş yapısını başarılı bir şekilde taklit etme şansını arttırmaktadır, ek olarak nanodoldurucular, siyah bir arka zemine yerleştirildiklerinde mavi ışık yaymakta, bu da bu tür kompozitlerde ışık efektlerinin oluşturulmasını kolaylaştırmaktadır. Mitra ve ark. ${ }^{16}$ nanokompozitlerin optik ve fiziksel özelliklerini inceledikleri çalışmalarında, bu kompozitlerin mikrofil kompozitlerle benzer şekilde yüksek translusensi, iyi cila ve tutuculuk özellikleri göstermesinin yanı sıra fiziksel özelliklerinin ve aşınma dirençlerinin de hibrit kompozitlerle benzer olduğunu belirtmişlerdir. Bu sonuçlar doğrultusunda nanokompozitlerin hem ön hem de arka dişlerin restorasyonunda kullanılabileceği rapor edilmiştir. Yapılan çalışmalar nanokompozitlerin daha iyi bitirme ve polisaj özelliklerine sahip olduğunu, aynı zamanda uzun dönemde aşınmalarının mikrofil ve hibrit kompozitlere oranla daha az olduğunu göstermektedir. ${ }^{37,38}$

Çok düşük opasite gösteren nanokompozitlerin üretilmesiyle, çoklu tabakalama tekniğiyle yapılan restorasyonlarda insizal kenarlar için ihtiyaç duyulan translusent renk seçeneklerinden mine ve dentin için gerekli olan opak renk seçeneklerine kadar geniş bir renk skalası ve opasite özellikleri sağlanabilmekte, bunun sonucunda da istenilen optik efektler oluşturulabilmektedir. ${ }^{13}$

Nanomerik partikül ve nanoöbek kombinasyonunu Filtek Supreme Plus (3M ESPE, St.Paul, ABD) başlatmıştır. Amacı, nanoboyuttaki partikülleri kullanarak (2-75 nm aralığında opaklığa bağlı) 'bottom-up' (aşağıdan yukarıya) sistemle dizayn edilen büyük kümeleri (0.6-1.4 $\mu \mathrm{m}$ ) parçalayarak daha iyi aşınma direnci sağlamaktır. Bunun sonucunda daha pürüzsüz yüzey elde edilmektedir. Küme yapıya sahip olan bu materyallerin fiziksel ve mekanik özellikleri geleneksel kompozit rezinlere göre farklıdır. ${ }^{16}$
Jung ve ark.nın ${ }^{15}$ yaptıkları bir çalışmada, 4 nanokompozit ile 1 hibrit kompozitin bitirme ve parlatma işlemlerinden sonraki yüzey pürüzlülükleri karşılaştırılmıştır. Çalışma sonuçları, nanodolduruculu kompozitlerde, hibrit kompozitten belirgin şekilde daha düzgün yüzeylerin elde edildiğini ortaya koymuştur. Bunun sebebi nanokompozitlerin çok daha küçük boyutta ve daha fazla miktarda doldurucu içermesidir. ${ }^{39}$

Ergücü ve ark. ${ }^{40}$ ise farklı nanokompozitlerin radyoopasitelerini karşılaştırmışlardır. Çalışmada kullanılan nanokompozitler, radyopoasite sağlayan zirkonyum, baryum, iterbiyum gibi x-ışınlarını absorbe etme özelliğine sahip doldurucu içermektedirler. Çalışmada en yüksek radyoopasiteyi Tetric EvoCeram'ın (Ivoclar Vivadent, Schaan, Liechtenstein), göstermesi rezinin içerdiği baryum ve iterbiyum triflorüre bağlanırken; CeramX (Dentsply DeTrey, Konstanz, Almanya) ve Tetric EvoCeram'in (Ivoclar Vivadent, Schaan, Liechtenstein) diğer kompozitlere oranla daha yüksek radyodensite göstermelerinin yapılarında bulunan seramik parçacıklarına bağlı olduğu iddia edilmiştir.

Kurtulmuş-Yılmaz ve ark. ${ }^{41}$ ev tipi beyazlatma ajanlarının (hidrojen peroksit ve karbamid peroksit) farklı dolduruculara sahip kompozit rezinlerin renk ve translusensi üzerine etkilerini incelemişlerdir. Çalışmanın sonucunda tüm kompozit rezinlerin beyazlatma sonrası renk değişimlerinin klinik olarak kabul edilebilir seviyenin üzerinde olduğu, ancak ormoser bazlı nanohibrit kompozit rezin olan CeramX Mono'nun (Dentsply DeTrey, Konstanz, Almanya) renk değişiminin en fazla olduğu bildirilmiştir.

Kompozitlerin aşınmaya karşı gösterdikleri direnç, ortamın ISISI, yetersiz polimerizasyon, iç pörozite, su absorpsiyonu ve rezinin türünden etkilenmektedir. Rezinlerin partikül büyüklüğü, oranı, şekli, hastanın alışkanlıkları ve okluzyonu aşınma hızına etki eden diğer önemli faktörlerdir. Fiziksel ve patolojik koşullar restorasyonda aşınmaya sebep olabilmektedir. Çiğneme veya bruksizm restorasyonun atrizyonuna, karşıt dişte de madde kaybı ve anatomik formun kaybına sebep olabilmektedir. Genellikle hibrit kompozitler mükemmel aşınma direnci göstermektedir. ${ }^{42}$

Curtis ve ark. ${ }^{43}$ nanodolduruculu ve konvansiyonel kompozit rezinleri kısa ve uzun dönem su emilimleri ve fiziksel özellikleri bakımından kıyaslamışlardır. Çalışmanın sonucunda materyallerin boyut ve

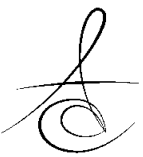


morfolojik faktörlerinden etkilendiği, nanodoldurucu içeren materyallerde nanopartiküllerin ve nanoöbeklerin bulunmasının mikrohibrit kompozitlere göre üstünlük sağladığı bildirilmiştir.

Turssi ve ark. ${ }^{44}$ farklı nanokompozitlerdeki aşınma ve yorulma direncini mikrofil kompozitlerle karşılaştırarak değerlendirdikleri çalışmalarında, nano yapılı kompozit rezinlerin aşınma ve yorulma dirençlerini mikrofil kompozitlerle benzer ya da mikrofil kompozitlerden daha düşük bulmuşlardır.

Yap ve ark. ${ }^{38} 8$ farklı kompozit rezinin yüzey düzgünlüğünü karşılaştırdıkları çalışmalarında, nanomer ve ormoser bazlı kompozitlerde, mikrodoldurucu ve nanoöbek içerenlere göre daha pürüzsüz yüzey elde edildiğini bildirmişlerdir. Bu kompozitlerin yüzeylerinin cam iyonomer ve kompomere göre daha pürüzsüz olduğu görülmüştür. Bitirme ve cila işlemlerinden sonra ormoser ve nanodolduruculu kompozitlerin yüzey pürüzlülük değerlerinin, mikrodolduruculu ve nanoöbek içeren kompozitlere göre belirgin biçimde daha düzgün olduğu bildirilmiştir.

Tanimoto ve ark. ${ }^{45}$, doldurucu partikül boyutlarının kompozit rezinlerin bükülme özellikleri üzerindeki etkisini değerlendirmişlerdir. Bu çalışmada 3.3-15.5 $\mu \mathrm{m}$ aralığındaki silika doldurucuların etkisi incelenmiştir. Araştırma sonuçları, ortalama doldurucu partikül çapı arttıkça bükülme dayanıkılığının azaldığını ortaya koymuştur.

Beun ve ark. ${ }^{46}$; nanodolduruculu, universal hibrit ve mikrodolduruculu kompozitlerin inorganik kısmı ve fiziksel özelliklerini karşılaştırmışlar ve nanokompozitlere ait elastikiyet modülünün diğer kompozitlere göre daha yüksek olduğunu bildirmişlerdir. Çalışmada değerlendirilen tüm kompozitlerin benzer bükülme dayanıklıı̆ı gösterdiğini, mikrodoldurucu kompozitin (Z-100, 3M-ESPE, St.Paul, ABD) fiziksel özelliklerinin düşük olduğunu bulmuşlardır.

Oxman ve ark. $^{33}$ tarafından yapılan bir çalışmada nanoiyonomer restoratif materyallerin cilalanabilirlik, aşınma direnci ve estetik özellikleri karşılaştırılmıştır. Çalışmada nanohibrit rezin modifiye cam iyonomer (Ketac N100 3M ESPE, St. Paul, ABD), 2 farklı rezin modifiye cam iyonomer (Fuji II LC ve Fuji Filling LC, GC Corporation, Tokyo, Japonya) ve nanohibrit kompozite (Tetric Evo Ceram, Ivoclar Vivadent, Schaan, Liechtenstein) yer verilmiştir. Çalışmanın sonucunda; nanoiyonomerik restoratif materyalin (Ketac N100) hibrit kompozite benzer cilalanabilme özelliği gösterdiği, diğer 2 rezin modifiye cam iyonomer simandan bariz olarak daha iyi cilalanabildiği ve aşınma oranının daha düşük olduğu bulunmuştur.

\section{Diş Hekimliğinde Nanoteknolojinin Geleceğe Yönelik Olası Uygulama Alanları}

Diş hekimliğinde nanoteknolojinin gelecekteki öngörülen uygulama alanları, aşağıdan yukarıya (bottom-up) yaklaşımıyla elde edilen yöntemlere örnek olarak gösterilebilir.

\section{Anestezi İndüksiyonu}

Lokal anesteziklerin enjeksiyonu, diş hekimliğinde en çok kullanılan, aynı zamanda hastaların rahatsız olması ve çeşitli komplikasyonlara yol açabilmesi bakımından dezavantajlara sahip bir uygulamadır.

Çok yakın bir gelecekte oral anestezinin nanodişhekimliğindeki kullanımını öngörecek olursak; milyonlarca aktif analjezik nanopartikül, kolloidal bir süspansiyonun içerisinde hastanın dişetine yerleştirilecektir. Nanorobotların kron yüzeyi ve mukozayla temas ettikten sonra gingival sulkustan dentine ulaşması, devamında lamina propria veya 1-3 $\mu \mathrm{m}$ kalınlığında olan mine-sement birleşimindeki gevşek dokudan ağrısız olarak geçmesi sağlanacaktır. Dentine ulaşacak olan nanorobotlar 1-4 $\mu \mathrm{m}$ çapındaki dentin tübüllerine girecek ve pulpaya doğru ilerleyecektir. Dentin tübüllerinin çapları pulpaya yaklaştıkça artar, bu da nanorobotların hareketlerini kolaylaştıracaktır. ${ }^{2}$ Analjezik dental nanorobotlar pulpaya ulaştıktan sonra impuls iletiminin kontrolü sağlanacaktır. Bu sayede uygulayıcı, tedavisi planlanan dişte tüm iletimi kesme imkanına sahip olacaktır. Tedavi işlemleri bittikten sonra aynı sistemle nanorobotların sinir iletimini baskılayıcı etkileri de kaldırılabilecektir. Son işlem olarak da nanorobotların aspire edilmesi gerekecektir.

Nanorobotik analjezikler, üst seviyede hasta konforu sağlamanın yanı sıra enjeksiyonun olmaması nedeniyle hastalarda anksiyeteyi de azaltacaktır. Bu karmaşık gibi görünen sistem sayesinde analjezik etkinlik seçilebilecek, kontrol edilebilecek, işlem çok hızlı gerçekleşecek ve tamamen geri dönüşümlü olacaktır. Yan etki ve komplikasyon bakımından da oldukça avantajlı bir uygulama olacağı düşünülmektedir. ${ }^{4}$

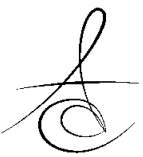




\section{Majör Diş Replasmanı}

Major diş replasmanı için nanodental teknikler; genetik mühendisliği, doku mühendisliği ve doku rejenerasyonu gibi alanlardaki teknolojik gelişmeler sayesinde ilerleme göstermektedir.

Etsuko ve ark. ${ }^{47}$ fareler üzerinde yaptıkları çalışmada kök hücrelerden elde ettikleri dişin transplantasyonunu başarıyla gerçekleştirmişlerdir. Bu, biyomühendislik ürünü olan diş tam fonksiyonel, ısırma ve beslenmede sorunsuzca işlev göstermiştir. Zihinlerde çığır açan bu hamleye rağmen diş morfogenezisi ve diş rejenerasyonunu tümüyle kontrol edecek teknoloji henüz keşfedilmediğinden, insanlar üzerindeki deneylere geçilmesi için biraz daha zaman ihtiyaç olduğu düşünülmektedir. Biyolojik olarak bir dişin hem mineral hem de sellüler komponentlere sahip otoloğunun hazırlanabilmesi, ancak zaman içerisinde mümkün olabilecektir.

\section{Renatüralizasyon}

$\mathrm{Bu}$ yöntem sayesinde hastaların eski amalgam dolguları kaldırılarak doğal biyomateryaller ile değiştirilecektir. Bu uygulamalar dolgulu, kronlu ya da doğal dişten ayırt edilebilen, işlem uygulanmış tüm dişler için geçerli olacaktır. Etkilenmiş dişlerin bu teknikle yeniden oluşturulması sayesinde doğal dentisyondan ayırt edilemez yapılar oluşturulabilecektir. Bu yöntemin hayat bulmasıyla estetik diş hekimliğ açısından mükemmel tedavi imkanları sağlanmış olacaktır. $^{3}$

\section{Dentifrobotlar}

Gelecekte mümkün olması öngörülen bir diğer uygulama da dentifrobotlardır. Bu nanorobotlar plak ve diğer bölgelerde bulunan patojenik bakterileri tanıma ve yok etme özelliğine sahip olacaklardır. Aynı zamanda normal florada bulunan 500'e yakın zararsız türü etkilemeyecek ve sağlıklı bir ekosistem oluşumuna yardım edeceklerdir.

Dentifrobotlar, oral malodorun en büyük sebeplerinden biri olan bakteri putrefaksiyon ürünlerini ortadan kaldırarak halitozis için de sürekli bir bariyer oluşturacaktır. Bu şekilde günlük dental işlemlerin genç yaştan itibaren sağlanması sayesinde diş kaybı ve gingival hastalıklar ortadan kalkacaktır. ${ }^{4}$

Ayrıca, geliştirilecek rekonstrüktif dental nanorobotlar doğal biyomateryalleri kullanarak dentin tübüllerin kısa süre içinde tamamen tıkamasına yardımcı olacak, böylece hastada dentin hassasiyeti açısından hızlı ve kalıcı bir iyileşme sağlanacaktır. ${ }^{3}$

\section{Diş Repozisyonu}

Gelecekte tasarlanacak ortodontik nanorobotlar gingiva, periodontal ligament, sement ve alveolar kemik de dahil olmak üzere tüm periodontal dokuları direkt olarak manipule edebilir özelliklere sahip olacaklardır. Dişlerin düzeltilmesini, rotasyona uğratılmasını veya vertikal olarak yeniden pozisyonlandırımalarını ağrısız şekilde kısa sürede gerçekleştirebileceklerdir. $^{3}$

\section{SONUÇ}

Dinamik bir ortam olan ağzın içerisinde yapılacak restorasyonlar birçok faktörün etkisi altındadır. Restoratif materyalleri tercih ederken bu parametreleri göz önünde bulundurmanın önemi kadar; elde edilecek ağız ve diş sağlığı, çiğneme fonksiyonu, fonasyon ve estetiğin yeniden kazandırılması restoratif diş hekimliğinin amaçlarının başında gelmektedir. Nanoteknolojinin sunduğu yeni imkanlarla geliştirilen yeni materyal, yöntem ve cihazlarla diş hekimliğinin tüm alanlarında özellikle de restoratif diş hekimliğinde de uygulanacak tedavilere ait parametrelerin geliştirilmesi sağlanmıştır. Nanoteknoloji alanındaki gelişmeler devam ettikçe restoratif diş hekimliği alanında da yeni ufuklar açılmaya devam edecektir.

\section{KAYNAKLAR}

1. Feynman RP. There's Plenty of Room at the Bottom. Eng Sci 1960;23:22-36.

2. Taniguchi N. On the Basic Concept of Nanotechnology. 1 ed. Tokyo: Japan Society of Precision Engineering: 1974. p. 18-23.

3. Freitas RJ. Nanodentistry. J Am Dent Assoc 2000;131:1559-65.

4. Patil M, Mehta DS, Guvva S. Future İmpact of Nanotecnology on Medicine and Dentistry. J Indian Soc Periodontol 2008;12:34-40.

5. Kocaefe Ç. Nanotıp: Yaşam Bilimlerinde Nanoteknoloji Uygulamaları. Hacettepe Tıp Derg 2000;38:33-8.

6. Freitas RJ. What is Nanomedicine? Nanomedicine 2005;1:2-9. 
7. Ozak ST, Ozkan P. Nanotechnology and Dentistry. Eur J Dent 2013;7:145-51.

8. Craig $B D$, Mitra $S B$, Kobussen GA, Doruff MC, Lechuga HL, Atkinson MR. Polish Retention Comparison of Experimental and Commercial Restorative Composite Materials. J Dent Res 2009;88:1506.

9. Fortin $D$, Vargas MA. The Spectrum of Composites: New Techniques and Materials. J Am Dent Assoc 2000;131:26-30.

10. Hervás-García A, Martínez-Lozano MA, CabanesVila J, Barjau- Escribano A, Fos-Galve P. Composite Resins. A Review of the Materials and Clinical Indications. Med Oral Patol Oral Cir Bucal 2006;11:215-20.

11. Summitt JB, Robbins JW, Schwartz RS. Fundamentals of Operative Dentistry: A contemporary Approach. 2 Ed. Illinois; Quintessence Publishing Co, Inc: 2006. p. 261-88.

12. Roberson TM, Heymann HO, Swift Jr EJ. Sturdevant's Art\&Science of Operative Dentistry. 5 Ed. St. Louis; CV Mosby: 2002. p. 473-99.

13. Subramani K, Ahmed W. Emerging Nanotechnologies In Dentistry 1 Ed. Oxford; Elsevier: 2012. p. 1-14.

14. Gürmen S, Ebin B. Nanopartiküller ve Üretim Yöntemleri - 1. İ.T.Ü., Metalurji ve Malzeme Mühendisliği Bölümü, Metalurji Dergisi 2008;150:31-8.

15. Jung M, Sehr K, Klimek J. Surface Texture of Four Nanofilled and One Hybrid Composite After Finishing. Oper Dent 2007;32:45-52.

16. Mitra SB, Wu D, Holmes BN. An Application of Nanotechnology in Advanced Dental Materials. J Am Dent Assoc 2003;134:1382-90.

17. deMonredon S, Cellot A, Ribot F, Sanchez C, Armelao $L$. Stabilization of sol-gel derived tin oxide particles. J Mater Chem 2002;12:2396-400.

18. Ferracane JL. Resin Composite-State of the Art. Dent Mater 2011;27:29-38.

19. Gökçe K, Özel E. Kompozit Restorasyonlarda Son Gelişmeler. Atatürk Üniv Diş Hek Fak Derg 2005; 15:52-60.

20. Dayangaç GB. Kompozit Rezin Restorasyonlar. 1 Ed. Quintessence Yayıncllık Istanbul: 2011. p. 414.
21. Gao F, Culbertson BM, Tong Y, Schricker SR. Evaluation of Multi-Methacryl-Poss for Potential Organic-Inorganic Hybrid Dental Restorative Materials. Polym Prep Div Polym Chem Am Chem Soc 2000;41:580-1.

22. Moisescu C, Vroom Z, deWith G. Synthesis of Nanoapatite Crystals. Phosphorus Res Bull 2002;13:193-6.

23. Kong LX, Peng Z, Li SD, Bartold M. Nanotechnology and Its Role in the Management of Periodontal Diseases. Periodontol 2000 2006; 40:184-96.

24. Atai M, Solhi L, Nodehi A, Mirabedini SM, Kasraei S, Akbari K, Babanzadeh S. PMMA-grafted Nanoclay as Novel Filler for Dental Adhesives. Dent Mater 2009;25:339-47.

25. Xu HH, Weir MD, Sun L. Nanocomposites With Ca And $\mathrm{PO}_{4}$ Release: Effects Of Reinforcement, Dicalcium Phosphate Particle Size And Silanization. Dent Mater 2007;23:1482-91.

26. Li G, Wang L, Ni H, Pittman CU. Polyhedral Oligomeric Silsesquioxane (POSS) Polymers and Copolymers: a review. J Inorg Organomet Polym 2002;11:123-49.

27. Davidson RS, Kolb BU, Anderson DB, Higgins JA, Hendrickson MJ, Brady JT. Zirconia Particles, Us Patent 2007;7:241-437.

28. Nagano $F$, Selimovic $D$, Noda M, Ikeda $T$, Tanakaa T, Miyamoto $Y$, Koshiro K, Sano H. Improved Bond Performance of a Dental Adhesive System Using Nano-technology. Biomed Mater Eng 2009;19:24957.

29. Dhuru VB. Contemporary Dental Materials. 1 ed. USA: Oxford University Press. 2004. p. 66-80.

30. Blaes J, Pearls for your practice. Dent Econ 2007;97:154-6.

31. Falsafi A, Madsen VJ, Mitra SB, Oxman J, Ton TT. A novel nano-ionomeric restorative with improved polish and wear-resistance. J Dent Res 2008;87: 244.

32. Bui HT, Falsafi A, Mitra S, Oxman J, Ton T. Fluoride Release of a new Nano-Ionomer Restorative Material. J Dent Res 2008;87: 987.

33. Oxman JD, Falsafi A, Mitra S, Ton TT, Madsen VJ, Bui HT. Improved Polish, Wear-Resistance and Esthetics of Nanoionomer Restorative Materials. J Dent Res 2008;87:0039.

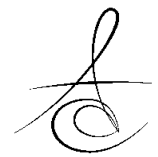


34. Prentice LH, Martin JT, Burrow MF. The effect of ytterbium fluoride and barium sulphate nanoparticles on the reactivity and strength of a glass ionomer cement. Dent Mater 2006;22:74651.

35. Kaya T, Tirali RE. Cam İyonomer Simanlardaki Gelişmeler. Atatürk Üniv Diş Hek Fak Derg 2013;7:71-7.

36. Moshverinia A, Ansari S, Movasaghi Z, Billington RW, Darr JA, Rehman IU. Modification of Conventional Glass-Ionomer Cements with NVinylpyrrolidone Containing Polyacids, NanoHydroxy and Fluorapatite to Improve Mechanical Properties. Dent Mater 2008;24:1381-90.

37. Craig BD, Mitra SB, Kobussen GA, Doruff MC, Lechuga $\mathrm{HL}$, Atkinson MR. Polish Retention Comparison of Experimental and Commercial Restorative Composite Materials. J Dent Res 2009; 88:1506.

38. Yap AU, Yap SH, Teo CK, Ng JJ. Comparison of Surface Finish of New Aesthetic Restorative Materials. Oper Dent 2004;29:100-4.

39. Senawongse $P$, Pongprueksa P. Surface Roughness of Nanofill and Nanohybrid Resin Composites After Polishing and Brushing. J Esthet Restor Dent 2007;19:265-73.

40. Ergücü $Z$, Önem $E$, Türkün LŞ, Güneri $P$, Boyacıoğlu H. Farklı Nanokompozitlerin Radyoopasitelerinin Karşılaştırılması. Selçuk Üniv Diş Hek Fak Derg 2007;16:1-7.

41. Kurtulmuş-Yılmaz S, Cengiz E, Ulusoy N, Ozak ŞT, Yuksel E. The Effect of Home-bleaching Application on the Color and Translucency of Five Resin Composites.J Dent 2013;41:70-5.

42. Heintze SD, Cavalleri A, Forjanic M, Zellweger G, Rousson V. A Comparison of Three Different Methods for the Quantification of the in Vitro Wear of Dental Materials. Dent Mater 2006;22:1051-62.

43. Curtis AR, Shortall AC, Marquis PM, Palin WM. Water Uptake and Strength Characteristics of a Nanofilled Resin-Based Composite. J Dent 2008;36:186-93.

44. Turssi CP, Ferracane JL, Ferrance LL. Wear and Fatigue Behavior of Nano-Structured Dental Resin Composites. J Biomed Mater Res B Appl Biomater 2006;78:196-203.
45. Tanimoto Y, Kitagawa T, Aida M, Nishiyama N. Experimental and Computational Approach for Evaluating the Mechanical Characteristics of Dental Composite Resins With Various Filler Sizes. Acta Biomater 2006;2:633-9.

46. Beun S, Glorieux T, Devaux J, Vreven J, Leloup G. Characterization of Nanofilled Compared to Universal and Microfilled Composites. Dent Mater 2007;23:51-9.

47. Etsuko I, Takashi T. Growing Bioengineered Teeth From Single Cells: Potential for Dental Regenerative Medicine. Expect Opin Biyol Ther 2008;8:735-44.

\section{Yazışma Adresi}

Esra Cengiz, DDS, PhD

Yakın Doğu Üniversites

Diş Hekimliği Fakültesi,

Restoratif Diş Tedavisi Anabilim Dalı, Lefkoşa, KKTC

E mail: dtesracengiz@yahoo.com

Telefon: 0 (392) 6802030 